DOI: $10.4274 /$ tpa.68

\title{
A rare condition: subgroup incompatibility due to anti-E
}

\section{To the Editor}

While immune hydrops occurs mostly in relation with $A B O$ and $\mathrm{Rh}$ incompatibility (95-97\%), it occurs rarely in relation with subgroup incompatibility (3-5\%) (1).

Subgroup incompatibilities lead to neonatal hemolytic anemia with varying degrees, prolonged jaundice and rarely immune hydrops. The most common subgroup incompatibilities which lead to blood incompatibility between the mother and the baby include $\mathrm{C}, \mathrm{C}, \mathrm{E}, \mathrm{e}$ antigens in the $\mathrm{Rh}$ system and $\mathrm{K}$ antigene in the Kell system. $14 \%$ of the subgroup incompatibilities are related to anti-E antibody (2). The clinical picture related to antiE mostly consists of mild-moderate anemia and prolonged jaundice; hydrops fetalis is observed rarely (3).

In the literature, cases of hemolytic anemia related to anti-K, anti-E, anti-C subgroup incompatibility have been rarely reported $(4,5,6,7,8,9)$.

In this letter, we wished to report a rare case of hydrops fetalis which developed in the neonatal period as a result of antiE subgroup incompatibility.

Our patient was born by cesarean section at the 34th gestational week because of pleural fluid and fetal distress with a birth weight of $2200 \mathrm{~g}$ as the first live birth from the first pregnancy of a 26-year-old mother (G1A0P1). The patient who appeared pale and edematous was intubated in the delivery room and was internalized in the neonatal intensive care unit. Diffuse edema was found on physical examination. The apical heart beat was found to be $190 / \mathrm{min}$ and the blood pressure was found to be $70 / 40 \mathrm{mmHg}$. The patient had hepatosplenomegaly and a $3 / 6$ systolic murmur. Neurologic examination revealed marked hypotonia and weak newborn reflexes. The laboratory tests were as follows: the blood type of the baby: $0 \mathrm{Rh}(-)$, the blood type of the mother: ARh (+), direct Coombs test: negative. Hemoglobin: $11 \mathrm{mg} \mathrm{dL}$, hematocrite: 34\%, lökosit: $9050 / \mathrm{mm}^{3}$, platelets: $17000 / \mathrm{mm}^{3}$ and reticulocyte: $8 \%$. Peripheral smear revealed $55 \%$ neutrophils, $33 \%$ lymphocytes, $12 \%$ normoblasts and fragmented erythrocytes and quartet platalet aggregations.
Pathological biochemical tests were as follows: total protein: 2.5 g/dL, albumin: $1 \mathrm{~g} / \mathrm{dL}, \quad N a: 128 \mathrm{mEq} / \mathrm{L}$, total bilirubin: $4 \mathrm{mg} / \mathrm{dL}$. On the postero-anterior lung graphy, fluid was found in bilateral fissures. On thoracal ultrasonography (USG), pleural fluid (13 $\mathrm{mm}$ in the right and $11 \mathrm{~mm}$ in the left) was observed. On abdominal USG, a small amount of freee fluid was found. Cranial USG was normal. Thoracentesis was performed and transudate fluid was evacuated. Fluid was restricted because of hyponatremia and increased weight and phototherapy was started.

The results of the tests performed to determine nonimmune causes were as follows: TORCH-S (-), Parvovirüs B19 $(-)$, EBV $\lg \mathrm{M}(-)$ and reducing substance in urine (-). Chromosome analysis, metabolic screening tests, hemoglobin electrophoresis, glucose-6-P-dehydrogenase, echocardiography and electrocardiography were found to be normal.

Direct Coomb test was repeated because of exclusion of non-immune causes of hydrops, hemolysis findings and indirect hyperbilirubinemia and was found to be mildly positive. Thereupon, subgroup analysis was performed and anti-E antigen incompatibility was found. Intravenous immunoglobulin $(1 \mathrm{~g} / \mathrm{kg})$ was administered to the patient.

On the $5^{\text {th }}$ day, ventilatory support and phototherapy were discontinued. On the $13^{\text {th }}$ day, full enteral nutrition was started. During the treatment, albumin was administered for two times, erythrocyte suspension was administered for one time and thrombocyte suspension was administered for two times. On the 21st day, the patient was discharged without any problem. No problem was observed in the outpatient follow-up.

Joy et al. (3) found 283 anti-E incompatibilities in the study they performed between 1959 and 2004. In 32 of these pregancies, anemia in the newborn was found and hydrops was found only in one. In the literature, the rate of anti-E positivity was found to be $0,12 \%$ in 43000 women between 1994 and 1990. In only $5 \%$ of these, findings of anemia developed in the baby (10).

In the study performed recently by Karagol et al. (11) in our country, anti-E incompatibility was found in $28.3 \%$ of 106 
subgroup incompatibility cases, but hydrops was not found in these cases.

In subgroup incompatibilities, direct Coombs test is found positive with a rate of $33 \%$. A negative direct Coomb test is not a definite indicator of abscence of incompatibility.

Since subgroup incompatibility generally leads to mild anemia in the newborn baby, it can be frequently overlooked. However, it should be kept in mind that subgroup incompatibility may lead to severe anemia and severe hyperbilirubinemia requiring exchange transfusion and rarely to a clinical picture of hydrops fetalis. We wanted to remind of the necessity of further investigations to determine subgroup incompatibility in cases of hydrops fetalis.

Evrim Kıray Baş, Ali Bülbül, Sinan Uslu, Selda Arslan, Muhittin Çelik, Asiye Nuhoğlu

Şişli Ettal Education and Research Hospital, Neonatology Clinic, Istanbul, Turkey

\section{References}

1. Stoll BJ, Kleigman RM. The fetus and the neonatal infant. In: Behrman RE, Kleigman RM, Jenson HB, (eds). Nelson textbook of pediatrics 17th ed. Philadelphia: WB Saunders, 2004: 592-607.
2. Geifman-Holtzman O, Wojtowycz M, Kosmas E, Artal R. Female alloimmunization with antibodies known to cause hemolytic disease. Obstet Gynecol 1997; 89: 272-275.

3. Joy SD, Rossi KQ, Krugh D, O'Shaughnessy RW. Management of pregnancies complicated by anti-E alloimmunization. Obstet Gynecol 2005 ; 105: 24-28.

4. Aslan Y, Erduran E, Gedik Y, Mocan H, Yıldıran A, Soylu H. Kell C and $E$ subgroup incompatıbilities in neonates with indirect hyperbilirubinemia. Turkiye Klinikleri J Pediatr 1996; 5: 93-98.

5. Özkaya H, Bahar A, Özkan A, Kandemir F, Göçmen I, Mete Z. İndirekt hiperbilirubinemili yenidoğanlarda $A B O, R h$ ve subgrup (Kell, c,e) uyuşmazlıkları. Türk Ped Arş 2000; 35: 30-35.

6. Özkaya H, Kandemir F, Süleymanoglu S, Aydınöz S, Ersen A, Uğur E, Ataş E, Göçmen I. Anti-E antibody related hemolytic disease of newborn: case report. Nobel Medicus Dergisi 2006; 40: 571-574.

7. Bolat F, Bülbül A, Uslu S, Cömert S, Can E, Nuhoğlu A. Anti-Kell ve antiC alloimmünizasyonu: üç olgu sunumu. The Medical Bulletin of Sişli Etfal Hospital 2009; 43: 142-145.

8. Sarici SU, Alpay F, Yeşilkaya E, Ozcan O, Gökçay E. Hemolytic disease of the newborn due to isoimmunization with anti-E antibodies: a case report. Turk J Pediatr 2002; 44: 248-250.

9. Strohm PL, lams JD, Kennedy MS. Hemolytic disease of the newborn from anti-E: A case report. J Reprod Med 1988; 33: 404-406.

10. Zipursky A, Bowman JM. Isoimmune hemolytic diseases. In: Nathan DG, Oski FA, (eds). Hematology of infancy and childhood 4th ed. Vol 1. Philadelphia: WB Saunders, 1993: 44-73.

11. Karagol BS, Zenciroglu A, Okumus N, Karadag N, Dursun A, Hakan N. Hemolytic disease of the newborn caused by irregular blood subgroup (Kell, C, c, E, and e) incompatibilities: report of 106 cases at a tertiarycare centre. Am J Perinatol 2012; 29: 449-454. 